\title{
El "Fuego inextinguible" de Harun Farocki: Dialéctica y Didáctica de las Imágenes Visuales en la Contemporaneidad
}

\author{
The "Inextinguible Fire" of Harun Farocki: Dialectic and Didactics Visual Images in Contemporary
}

\author{
Isabel Molinas \\ Universidad Nacional del Litoral - Argentina \\ Isabelmolinas8@gmail.com
}

\begin{abstract}
The Farocki's exhibition in Fundación PROA (Buenos Aires, 2013) and the publication in Argentina of his essays produced between 1980 and 2011 (the Black Box Editor, 2013), support the relevance of the german filmmaker. In his works, the sense it reads in transit, at the edges, in the dialogue between screens and languages, and in the virtuosity detail. The purpose is to make the perception less automatic to humanize the images and bring back sense to them. In the field of Didactics Proyectual - under construction-, that artistic experience intensifies the perception and reconstructs the established repertoire of situational grammars, enabling teaching and learning experiences enriched.
\end{abstract}

Keywords: Audiovisual languages ; Rhetoric; Experience; Education; Didactics projective; Morphogenesis.

\section{Imágenes Para No Olvidar}

La reciente muestra antológica de Harun Farocki en Fundación PROA -organizada conjuntamente con el Goethe-Institut- (Buenos Aires, abril de 2013) y la publicación en Argentina de sus principales ensayos producidos entre 1980 y 2011 (la Caja Negra Editora, 2013), confirman la relevancia del cineasta alemán a la hora de pensar un repertorio de dispositivos tecnológicos y de regímenes visuales que vertebran la visualidad en las sociedades contemporáneas. Al respecto, entendemos que su incorporación en la formación de los Diseñadores puede favorecer la enseñanza de las dimensiones retórica, ética y política del campo disciplinar y, en tanto "imágenes potentes" (Perkins 1992), promover una reflexión epistemológica sobre el estatuto del Diseño de Comunicaciones Visuales y sobre el alcance de sus usos.

En palabras de Didi-Huberman (2009 [2013]: 14), el trabajo de Farocki propone pensar la manipulación de las imágenes, el movimiento dialéctico en que se funda la construcción del sentido y la posibilidad de transparentar las relaciones entre tecnología, historia y poder en la sociedad contemporánea. Cualquiera sea el lenguaje elegido -desde el documental en blanco y negro, hasta la video-instalación hecha de imágenes registradas por cámaras implantadas en misiles o simuladas por ordenadores-, Farocki despliega una estrategia en la que el significado debe leerse en el tránsito, en los bordes, en el diálogo entre pantallas y entre lenguajes, y en el virtuosismo del detalle que desautomatiza la percepción para volver a humanizar las imágenes.

El corpus propuesto para el análisis incluye: "Fuego inextinguible" (1969), “Ojo/Máquina II" (2002), "La Plata y la Cruz" (2010) y "Paralelo" (2012).
De "Fuego inextinguible" nos interesa la comparación y el desplazamiento metonímico a partir del cual Farocki hace comprensible la magnitud de los efectos de las bombas de Napalm. Sentado en un escritorio, con los puños cerrados sobre la mesa, el cineasta lee el testimonio de un sobreviviente $y$, para que el espectador comprenda la 'real dimensión' los efectos del gas, apaga un cigarrillo encendido sobre el lado interno de su brazo izquierdo. La voz del narrador en off agrega: "Un cigarrillo quema a 200 grados. El Napalm quema a 1700 grados." La escena trasciende la mera acción para convertirse en relato persuasivo que hace foco en cómo se dice el horror y cuáles son los efectos de las imágenes de la violencia sobre el espectador. Incluso, visto con cierta distancia -se vuelve a reponer en el 2009-, promueve una relectura crítica de los textos de Sontag (2003) y del mismo Didi Huberman (2003 [2004]), entre otros.

En “Ojo / Máquina II" (2002), proyección de dos videos sincronizados, de imágenes virtuales y de imágenes registradas en distintas guerras a lo largo de la historia, potencia la comprensión de los efectos de sentido de cada uno de los lenguajes utilizados y promueve una reflexión de nuevo tipo sobre los alcances de las imágenes en la producción y comprensión de los relatos y de los acontecimientos bélicos.

A partir de "La Plata y la Cruz" (2010) ahondamos en la naturaleza propedéutica del detalle en la lectura de imágenes y el modo en que dicho procedimiento resta ambigüedad y potencia a la totalidad de la pintura de Gaspar Miguel de Berrío (1758), a través de una operación recurrente que podemos interpretar en términos de sinécdoque. 
Finalmente, "Paralelo" (2012) es una indagación sobre el estatuto actual de las imágenes producidas por medios digitales y su relación con 'lo real'. Farocki vuelve a interrogarse sobre los alcances de cada construcción semiótica, en el interior y hacia los bordes de cada lenguaje, y redefine las relaciones entre 'lo real' y 'lo virtual'.

En resumen, a partir de trabajos de Harun Farocki producidos desde diferentes lenguajes se profundiza en el estatuto de los mismos y se transparenta la manera dialógica y dialéctica de construir la significación. Metonimia, sinécdoque y metáfora son, en la obra del cineasta alemán, medios para desautomatizar la percepción y volver a poner en marcha la maquinaria del sentido. Con un sentido próximo, en el campo de una didáctica específica del Diseño de Comunicaciones Visuales, la experiencia artística intensifica la percepción y contribuye a rearmar el repertorio establecido de gramáticas situacionales, posibilitando experiencias de enseñanza y aprendizaje enriquecidas (Dewey, 1934 [2008]).

\section{Imágenes Para Recordar}

Tal como lo reseñan Ehmann y Eshun (2009 [2013]: 294), Farocki incluye en sus textos escenas de enseñanza y aprendizaje:

En 2007, Tom Holert y Marion von Osten formularon el concepto de Erziehungsbild -imagen de la educación- para pensar tanto las maneras en las que la escena educativa aparece al interior de la cultura visual, como las maneras en las que la cultura visual funciona como un aparato de pedagogía. Esta imagen de la educación es claramente visible en la obra de Farocki de tres modos. Primero, en la forma de elementos tales como escritorios, máquinas de escribir, libros, diagramas y ecuaciones que constituyen escenografías de aprendizajes. Segundo, en la forma de escenas que dramatizan narrativas de aprendizaje. Tercero, el mismo director aparece, sentado en su escritorio, rodeado de libros y fotografías, como el sujeto del aprendizaje. Hoy, en el mundo del arte contemporáneo, la imagen de la educación es la máxima aberración posible; decir que una imagen es didáctica o pedagógica es lo peor que uno podría decir de una imagen, mucho peor que decir que una imagen es pornográfica. En la obra de Farocki este veredicto se revierte.

Ahora bien, ¿cuál es el alcance de la afirmación anterior? Qué nuevas relaciones es posible establecer entre Arte, Diseño y Educación?

Tanto el Arte como el Diseño participan hoy de un desplazamiento epistemológico que renueva las formas de preguntar, interpretar y trabajar con lo comprensible o lo sorprendente en el campo de las disciplinas proyectuales. Este desplazamiento pareciera estar en relación -de acuerdo con Graciela Speranza (2006: 23-24)- con una nueva expansión de los campos estéticos en la posmodernidad y con la transformación de soportes y lenguajes:
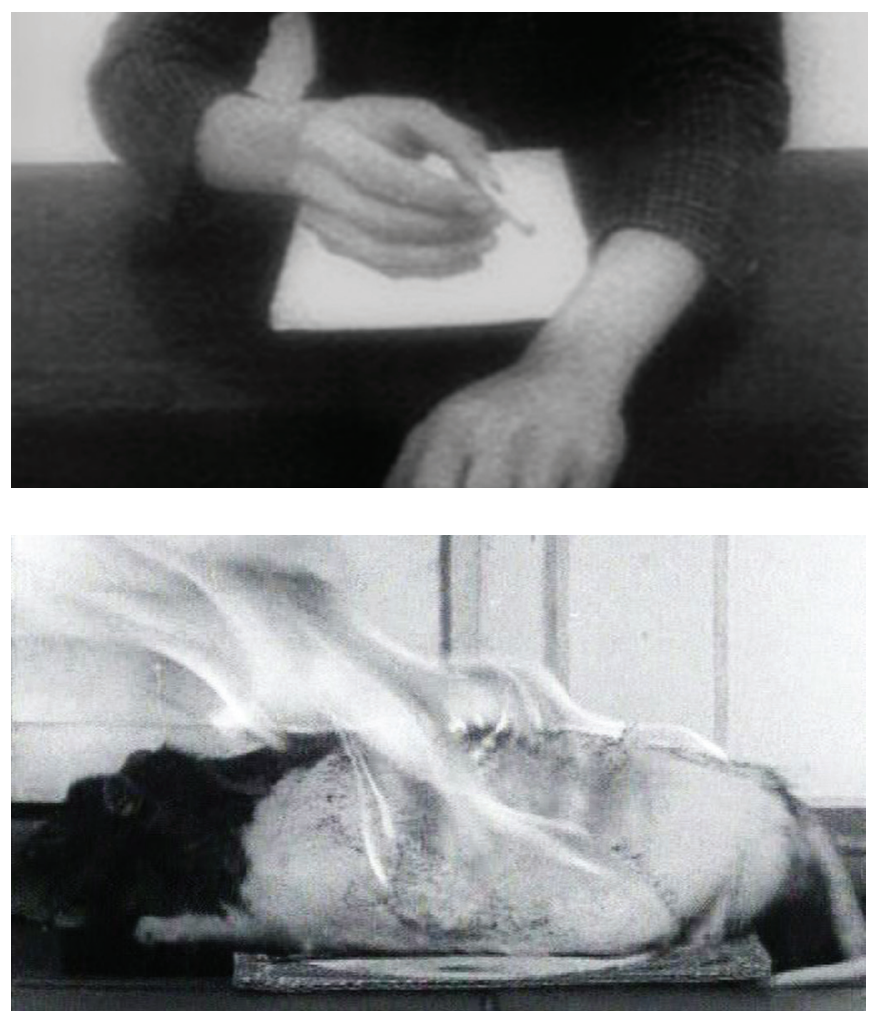

Figura 1 y 2: Fuego inextinguible (1969). Film b/n, 25 min.

La progenie de esa batalla es nutrida y deriva en la necesidad de transferir la hermeneútica o la semiótica del texto a la "lectura" de los artefactos visuales, y de "leer" la imagen con los saberes de la lectura del texto. "Según el saber como problema" escribe Deleuze a propósito de Foucault, "pensar es ver y es hablar, pero pensar se hace en el 'entre dos', en el intersticio o la disyunción del ver y del hablar. Pensar es inventar cada vez el entrelazamiento, lanzar cada vez una flecha desde uno mismo al blanco que es el otro, hacer que brille un rayo de luz en las palabras, hacer que se oiga un grito en las cosas visibles." (Speranza, 2006: 23-24)

El giro del cual Speranza nos habla no sólo es hacia la lingüística sino fundamentalmente hacia la filosofía y hacia la estética, y es por este camino que nos interesa transitar los desafíos de una Didáctica Específica que nos ayude a pensar en las prácticas de la enseñanza de las artes visuales en la contemporaneidad.

Casi cien años atrás, el pedagogo y psicólogo pragmatista John Dewey escribió:

Cuando digo que la única solución es poner a la total labor de la epistemología en relación con las condiciones que la dieron a luz y con la función que ha de desempeñar, quiero decir que el carácter no-satisfactorio del movimiento neo-kantiano, descansa en su suposición de que el conocimiento se da existencia a sí mismo y es capaz de facilitarse su propia justificación. La solución que siempre se busca y que jamás se encuentra en tanto 
que tratamos al conocimiento como proveedor suficiente por sí mismo de realidad, se revela cuando concebimos el conocimiento como una exposición para que la acción prosiga satisfactoriamente (Dewey, 1930: 535-536).

Como parte de este aprendizaje situado, Dewey advertía sobre la importancia metodológica de la comunicación para la comprensión de la experiencia:

Realizad el experimento de comunicar, con plenitud y precisión, alguna experiencia a otro, especialmente si es algo complicado, y encontraréis que ha cambiado vuestra propia actitud respecto a vuestra experiencia. La experiencia debe formularse para ser comunicada. Para formularla se requiere salirse fuera de ella, verla como la vería otro, considerar los puntos de contacto que tiene con la vida de otros, para que pueda adquirir tal forma que aquel sea capaz de apreciar su sentido (Dewey, 1916 [1998]: 16-17).

Esta necesidad de decir para que la acción prosiga satisfactoriamente puede ser abordada desde diferentes estrategias de enseñanza y aprendizaje. El diálogo y las comunidades de indagación, o la función epistemológica de la narrativa en la enseñanza, el aprendizaje y la investigación son algunas de ellas. La elección de una u otra estará en directa relación con los artistas con los que decidamos trabajar. Elegimos artistas que no ofrecen respuestas doctrinarias ni programas; elegimos artistas que en pleno ejercicio de su libertad dicen con metáforas las condensaciones y también las incertidumbres del sentido que no siempre conseguimos formular como conceptos (García Canclini, 2010: 12).

Didi-Huberman (2009 [2013]: 35) concluye su ensayo sobre Harun Farocki diciendo: "Elevar el propio pensamiento hasta el nivel del enojo, elevar el propio enojo hasta el nivel de una obra. Tejer esta obra que consiste en cuestionar la tecnología, la historia y la ley. Para que nos permita abrir los ojos a la violencia del mundo que aparece inscripta en las imágenes."

¿Qué decir y qué hacer, entonces, a contrapelo de la violencia del mundo ¿De qué manera intensificar la percepción y la cognición en el espacio del aula? ¿Qué funciones políticas y cognitivas podemos atribuirle a las imágenes? ¿Cuál es el alcance -en palabra de Bourriaud (2009: 7)- de una crítica del arte del mundo?

Asistimos a un giro transformador hacia el arte, renovador de los movimientos que aprendimos hacia la ciencia, hacia la filosofía o hacia la lingüística. Un giro que resignifica nuestras experiencias académicas y artísticas, y nos compromete en un proyecto que trasciende la geografía, que es compartido, transversal y profundamente democrático. Un movimiento que encuentra en los lenguajes del arte el dispositivo para problematizar las gramáticas situaciones aprendizajes y abrirnos a experiencias estéticas profundamente educativas.

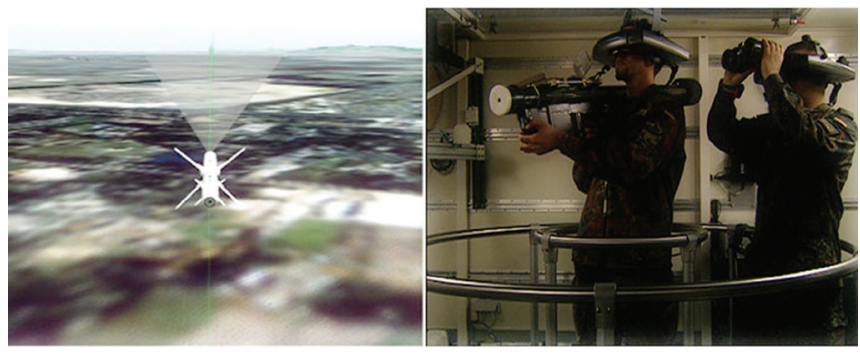

Figura 3: Ojo/Máquina II (2002). Video, color y b/n, versión de un solo canal, $15 \mathrm{~min}$

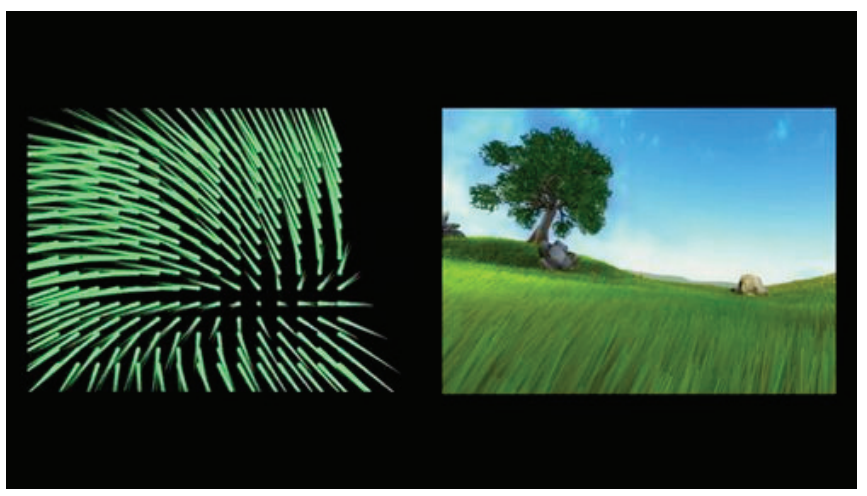

Figura 4: Paralelo (2012). Video-instalación. 2 canales de video HD. Color, sonido, $17 \mathrm{~min}$.

\section{Referencias:}

Bourriaud, Nicolás (2009) Radicante. Buenos Aires: Adriana Hidalgo.

Dewey, J. (1916) Democracia y educación. Una introducción a la filosofía de la educación. Madrid: Morata, 1998, 3o edición.

Dewey, J. (1930) Pedagogía y Filosofía. Madrid: Francisco Beltrán Editor.

Dewey, John (1934) El arte como experiencia. Barcelona: Paidós, 2008.

Didi-Huberman, George (2003) Imágenes pese a todo. Memoria visual del Holocausto. Barcelona: Paidós, 2004.

Didi-Huberman, G. (2009) "Cómo abrir los ojos". En Harun Farocki. Againt What? Against Whom?, de Antje Ehmann y Dodwo Eshun (eds.), Londres: Koening Books.

Ehmann, Antje y Eshun, Kodwo (2009) "De la A hasta la Z (O veintiséis introducciones a Harun Farocki). En Farocki, Harun (2013) Desconfiar de las imágenes. Buenos Aires: La Caja Negra.

Farocki, Harun (2013) Desconfiar de las imágenes. Buenos Aires: La Caja Negra. 
García Canclini, Néstor (2010) La sociedad sin relato. Antropología y Estética de la inminencia. Buenos Aires: Katz.

Perkins, David (1992) La escuela inteligente. Buenos Aires: Gedisa, 1995.

Sontag, Susan (2003) Ante el dolor de los demás. Buenos Aires: Anagrama.

Speranza, Graciela (2006) Fuera de campo. Literatura y arte argentinos después de Duchamp. Buenos Aires: Anagrama.

\section{Fotografías}

Fundación PROA: http://www.proa.org/esp/exhibition-harun-farocki.php

ARTISHOCK, Revista de Arte Contemporáneo: http://www.artishock.cl/2013/02/harun-farocki-el-poder-de-lasimagenes/ 